\title{
An Evaluation of Drugs Used in the Control of Stressful Stimuli in Domestic Animals: A Review
}

\author{
B. H. ALI, A. A. Al-QARAWI
}

Department of Veterinary Medicine, College of Agriculture and Veterinary Medicine, King Saud University, Al-Gaseem branch, Saudi Arabia

Received November 14, 2001

Accepted June 19, 2002

\begin{abstract}
Ali B. H., Al-Qarawi A. A.: Evaluation of Drugs Used in the Control of Stressful Stimuli in Domestic Animals: A Review. Acta Vet. Brno 2002, 71: 205-216.

There is no universal agreement on what constitutes a stressful stimulus in animals, methods of quantifying the animal response, or the ways by which stress can be ameliorated or prevented.

The effect of certain drugs on the clinical, biochemical, hormonal and other changes induced by various stressful stimuli in domestic animals is evaluated. The drugs reviewed include: sedatives that are adrenergic agonists and antagonists (such as xylazine, prazosin and acepromazine) dopamine, benzodiazepines (such as diazepam), opioid agonists (such as morphine), central nervous depressants (such as barbiturates), drugs with hormonal effects (such as metyrapone) and dietary substances (such as magnesium aspartate, tyrosine and ascorbic acid).

Most of these drugs are effective, to different degrees, in ameliorating some aspects of the changes induced by the stressful stimuli. Despite their different and often opposing mechanisms of action, they appear to antagonise one or more of the various aspects of the stress response. This is a reflection of the complexity of the stressful responses.

The use of drugs to ameliorate or prevent animal stress is ethically important, and may also be of use in improving our understanding of the complex physiological and behavioural aspects of stress. However, from a welfare point of view, the use of vitamins, amino acids and other dietary substances may provide a less expensive, and thus more readily available, alternative to other antistress drugs, if they can be shown to remove or, at least, mitigate a harmful consequence of the stress response. There may be also fewer side effects.

Animal stress, anti-stressor drugs, welfare aspects
\end{abstract}

The welfare of animals during periods that can inflict stress (such as transport, crowding, extreme ambient temperatures) has recently been highlighted (e.g. Warris 1995; Swiderska-Kolacz 1997; Blokhuis et al. 2000; Dobson et al. 2001). Codes and legislation for potentially stressful stimuli that may compromise animal welfare are nonexistent in many countries in the world, and are, at best, lax in others.

There is no universal agreement on what constitutes a "stressful" stimulus in animals, methods of quantifying the animal response, or the ways by which stress can be ameliorated or prevented.

Several aspects of the physiological and biochemical changes that accompany or follow stress in animals have been well documented, but the results obtained are at variance. Parameters used to evaluate stress or welfare are commonly based on sympatho-adrenal measures such as heart rate (Cook and Jacobson 1996), plasma hormones and metabolites (B obek et al. 1986) and immune indicators (Agnes et al. 1990). Assessment of animal welfare is complicated because most of these measures respond similarly to both physical and psychological stressors. Other measures may, however, respond to sympathetic activation that is not necessarily a reflection of stress in animals. Therefore, some authors suggested separation of psychological and physical contributions to stress (Hargreaves and Huston 1990; Jacobs on and Cook 1998). Several studies have focused on the use

Address for correspondence:

Badreldin H. Ali

P. O. Box 10158 Buraydah

Saudi Arabia

Phone: + 966-6-3813372

Fax: + 966-6-3813372

E-mail: alibadreldin@ hotmail.com
http://www.vfu.cz/acta-vet/actavet.htm

( 
of drugs in the mitigation or prevention of stress in domestic, wild and laboratory animals. For ethical and other reasons, such studies in humans are not conducted. However, the results of these studies may find applications in humans. The choice of these drugs as antistressors is either empirical, or based on an established or putative role of a certain neurochemical basis of stress. In addition to its use in the mitigation or prevention of stress, the use of drugs against stress can therefore be instrumental in a better understanding of the physiological and /or biochemical basis of stress. It should be realised, however, that improving the living and transportation conditions of animals to remove or, at least, minimise stressful stimuli may be ethically and economically better than using drugs to alleviate some or all the effects of a stressful procedure. Treatment of stressed domestic animals with anti-stressor drugs (especially those affecting the CNS) may pose some illeffects on treated animals (e.g. on posture, stability and locomotion), and on public health, especially when the treated stressed animals are intended for slaughter. Some of those drugs have relatively long withdrawal periods that may compromise profitability. Still, others may have residues that may be deleterious to human health. Therefore, for certain drugs, issues of safety and cost may detract from their use to alleviate stress in animals. As mentioned above, it may be considered more ethical to remove or modify the stressor to minimise the stress rather than to employ drugs to reduce the stress.

Several productive, physiological and biochemical aspects of various types of stress in animals have recently been reviewed (see e.g. Phogat et al. 1997; Knowles 1998; Dobson et al. 2001). The following article will attempt to enlist and comment on some of the drugs that were reported to be of value against various stressful stimuli, mainly in domestic animals.

\section{Drugs used in stressed domestic animals}

Drugs that were used in domestic animals to alleviate clinical and biochemical signs of stress include: sedatives (adrenergic agonists and antagonists), dopamine, opioids, benzodiazepines, opioids, CNS depressants (barbiturates), drugs with hormonal effects (metyrapone) and dietary substances. The following is an account of some of these drugs.

\section{Sedatives \\ 1.1. Adrenergic agonists \\ 1.1.1. Xylazine}

This is an alpha 2 receptor agonist that acts on both the peripheral and central nervous system (CNS), producing sedation, analgesia and muscle relaxation. Because it was thought that some types of stressful stimuli might involve the adrenergic system, the effects of some alpha $_{2}$ adrenergic agonists have been studied. These include xylazine in cows and goats subjected to transport stress (Brearley et al. 1990; Sanhouri et al. 1992) and in turkey poults subjected to immobilisation stress (Ali et al. 1987). In the study of Sanhouri et al. (1992) in goats subjected to transportation stress, xylazine $\left(0.01 \mathrm{mg} \cdot \mathrm{kg}^{-1}\right)$ suppressed resting plasma cortisol concentration, increased blood glucose level and suppressed respiratory and heart rates. Xylazine produced significant metabolic alkalosis after treatment (Brearley et al. 1990). Unlike xylazine, acepromazine treatment (see below) caused hypercortisolaemia but no hyperglycaemia. Both drugs induced metabolic alkalosis and decreased the haematocrit (Brearley et al. 1990). Cortisol concentrations were suppressed by xylazine treatment when administered before a 20 -min van journey, and for approximately $60 \mathrm{~min}$ when given $20 \mathrm{~min}$ after the start of a 2-h journey (Sanhouri et al. 1992). Xylazine pre-treatment did not alter the cortisol response to corticotrophin releasing factor (CRF), suggesting that xylazine must act centrally above pituitary level when blocking the cortisol 
response to transport. It was also postulated that under resting conditions, the hypothalamus is under alpha $a_{2}$ adrenergic suppression. Stimulation of cortisol secretion in response to a stressor can be inhibited by an alpha ${ }_{2}$ agonist.

Xylazine reduced the stress response in chickens stressed with handling (Nikpour and Salimi, 1979). In turkey poults subjected to immobilisation, xylazine $(5,10$ or $20 \mathrm{mg} / \mathrm{bird})$ reduced, in a dose-dependent manner, the stress-induced hyperprolactinaemia (Ali et al. 1987) which is considered as a reliable marker of stress in turkeys (El Halawani 1985). It was postulated that the anti-stressor action of xylazine might be a direct effect on the hypothalamo-hypophyseal axis.

The hyperglycaemic action of xylazine is generally ascribed to the synergistic actions of cortisol, catecholamines and glucagon, all of which are released in conditions that are termed stressful (Eiger et al. 1979). It has also been shown that xylazine-induced hyperglycaemia may be due to alpha-2 mediate inhibition of insulin release and increased hepatic mobilisation of glucose. A possible disadvantage of the use of xylazine in animals transported to abattoirs is the residues of the drug or its metabolites in the meat that could constitute a public health hazard.

\subsubsection{Medetomidine}

The stress-protective activity of medetomidine, in relatively low dose, was first shown in rats and mice subjected to swim stress (Rago et al. 1991). The drug was also reported to be devoid of any anxiolytic activity. Medetomidine was shown in vitro to be a selective alpha adrenoreceptor agonist, and also acts on GABA-potentiated benzodiazepine binding cites.

Recently, the effect of medetomidine on the stress response induced by ovariohysterectomy in isoflurane-anaesthetised dogs was studied by Benson and his colleagues (2000). Premedication with medetomidine safely and effectively prevented or delayed the surgery-induced stress response in these dogs. As there is much less experience with medetomidine than with xylazine, it is not possible to meaningfully compare the efficacy and safety of the two agents. However, the dose of medetomidine is only a fraction of that of xylazine, and this is a definite advantage because the risk of residues would be reduced.

More recently, Ranheim and colleagues (2000) have studied the effect of medetomidine followed by atipamezole on some biochemical indices of stress (namely the concentrations of plasma glucose, cortisol and noradrenaline) in calves and sheep. These workers have found that in these two species i.v. injection with medetomidine $\left(40 \mu \mathrm{g} \cdot \mathrm{kg}^{-1}\right)$ induced hyperglycaemia and hypercortisolaemia. The hyperglycaemia but not the hypercortisolameia was reversed when followed 60 min later by i.v. atipamezole $\left(200 \mu \mathrm{g} \cdot \mathrm{kg}^{-1}\right)$. The latter drug did not affect the cortisol levels except in sheep where an increase was observed. Medetomidine decreased the plasma concentration of noradrenaline indicating that it has inhibited the sympathetic activity in cattle and sheep. Atipamezole antagonised this action and induced a large increase in the concentration of noradrenaline. The authors concluded that medetomidine does not seem to reduce the overall endocrine stress response in cattle and sheep that was previously been reported in other species. More experimental work is warranted to verify the effects of medetomidine on indices of stress.

\subsection{Adrenergic antagonists}

1.2.1. Propranolol

Propranolol is a non-selective beta-adrenergic antagonist, widely used in human medicine against hypertension and other cardiovascular diseases. It is also used symptomatically in cases of hyperthyroidism and anxiety. Reports on the anti-stress action of this drug are at 
variance. The drug had little effect on the stress of hyperthermia and surgery in pigs. (Lister et al. 1976; Cooper et al. 1980). Others have shown that the drug was effective in reducing stress-induced biochemical and hormonal in man (Tsuji et al. 1980) and rat (Fahringer et al. 1974) Administration of propranolol $\left(0.05 \mathrm{mg} \cdot \mathrm{kg}^{-1}\right)$ to goats subjected to the stress of transportation failed to inhibit the cortical and glucose stress responses (Sanhouri et al. 1991b). However, the drug was, expectedly, effective in reducing the transport-induced increase in heart and respiratory rates. Based on the results on propranolol and prazosin (see below), the authors interpreted these results to imply that changes in the caprine plasma concentrations of cortisol and glucose during transport stress may not be mediated by either alpha or beta adrenergic mechanisms (S anhouri et al. 1991b).

\subsubsection{Acepromazine}

This is an alpha-adrenergic antagonist which is widely used in veterinary medicine in premedication prior to general anaesthesia and as a common sedative. In a comparative study, the sedative and anti-stressor effect of acepromazine and xylazine were studied in cows (Brearley et al. 1990). Acepromazine was injected intramuscularly (i.m.) at a dose of $0.05 \mathrm{mg} \cdot \mathrm{kg}^{-1}$ to cows subjected to the stress of transportation for five min to a different environment. Transport followed by saline injection produced significant increase in plasma cortisol concentration. Both drugs produced similar degrees of sedation. However, unlike with xylazine, injection of acepromazine without the stress of transport produced hypercortisolaemia, which was less in magnitude that that produced by the injection alone. The explanation of the cortisol release after acepromazine may lie in the fact that the drug, with its relatively long duration of action, might cause systemic release of adrenaline, which may result in an increase in adrenocorticotrophic hormone (ACTH) release and hence cortisol release. Acepromazine injection did not affect plasma glucose level. As stated above, hyperglycaemia is a consistent effect of xylazine. It was of interest to note that the increase in cortisol after the i.m. injection combined with short transport was greater in the work of Brearley and colleagues (1990) than that after an i.m. injection alone (Alam et al. 1986), but was less than that in response to prolonged transportation.

\subsubsection{Prazosin}

This alpha ${ }_{1}$ adrenergic antagonist was injected into three goats at an intravenous (i.v.) dose of $0.1 \mathrm{mg} \cdot \mathrm{kg}^{-1}$ (Sanhouri et al. 1991b). Two days later, the goats were transported in a van for $2 \mathrm{~h}$, and the next day prazosin was given $30 \mathrm{~min}$ after the start of a 2-h journey. Clinically, prazosin caused recumbency drowsiness and depression that lasted for one $h$. Prazosin alone caused hypercortisolaemia. Given to goats stressed with transport, the drug potentiated the hypercortisolaemia. The drug caused no consistent or significant effect on blood glucose or heart and respiratory rates. Moreover, prazosin did not affect transportinduced tachycardia. However, it was effective in suppressing the transport-stimulated respiratory rates, suggesting that alpha ${ }_{1}$ receptors may be involved in this stress response but not in the cortisol or glucose stress responses.

\section{Dopamine agonists and antagonists}

Stress is known to involve the release of dopamine (D), and dopaminergic drugs have been shown to affect the secretion of many hormones in several species (for a review see Feenstra 2000). A single communication studied the effect of azaperone $\left(D_{1}\right.$ and $D_{2}$ receptor antagonist), pimozide $\left(\mathrm{D}_{2}\right.$ antagonist $)$ or bromocryptine $\left(\mathrm{D}_{2}\right.$ agonist $)$ in three male goats before, during and after a 2-h motorised transportation (S anhouri et al. 1993). The three agents, either alone or when combined with transport, did not affect glucose 
concentration, probably indicating that $\mathrm{D}$ receptors have no direct involvement with catecholamine-induced glucose production.

Azaperone alone and with transport stress caused excitement, then sedation followed by recumbency. It also induced hypercortisolaemia. Pimozide, alone or during transport, induced sedation, recumbency and hypercortisolaemia. Bromocriptine induced drowsiness, recumbency and hypercortisolaemia when the drug was given alone. When administered during transportation, cortisol concentration was not significantly affected. However, after transport plus drug, cortisol values remained higher than the baseline for the sampling period $(6 \mathrm{~h})$. These results suggest that the D antagonists increase basal cortisol concentration, but suppress and/ or delay transport-induced hypercortisolaemia.

Although these results may be of interest in assessing the involvement of D receptors in stress, it seems unlikely that these $\mathrm{D}$ agonists and antagonists might be practicable agents to use in stressful situations in view of their inconsistent effect on cortisol level in blood and rather severe side effects (intermittent excitement/sedation and recumbency).

\section{Benzodiazepines}

Evidence for an effect of benzodiazepines on stress responses in domestic animals is controversial.

\subsection{Diazepam}

Fitko et al. (1982) reported that treatment with diazepam was effective in antagonising the haematological and biochemical changes induced by immobilisation in pigs. In ruminants, diazepam reduced cortisol concentration, heart rate and uterine activity during labour (Sanhouri et al. 1992c). Given at i.v. dose of $0.2 \mathrm{mg} \cdot \mathrm{kg}^{-1}$, to goats diazepam suppressed transport-induced hypercortisolaemia, hyperglycaemia, tachypnoea and tachycardia (Sanhouri et al. 1991c). A rebound increase in cortisol concentration, respiratory and heat rate were seen during the recovery period after sedation. However, using the same dose, others were unable to suppress the cortisol response to electroimmobilisation (Jephcott et al. 1988). The reason for this discrepancy is uncertain. It may be that electroimmobilisation may have exerted too great a stress for this dose of drug. Alternatively, diazepam may suppress certain inhibitory inter-neurones (which utilised GABA) in certain types of stressful stimuli but not others. An obvious drawback with benzodiazepines is that they are addictive controlled drugs that are liable to be misused, and are rather expensive to use in large numbers of animals.

\section{Opioids}

Opioids have been reported to have a beneficial role in reducing stress in arts (Tanaka et al. 1983). Morphine significantly attenuated stress-induced alleviation in brain noradrenaline metabolites, while naloxone (an opioid antagonist) had the opposite effect (Tanaka et al. 1982; Tanaka et al. 1983). The response of stressed animals to opioids seems to be particularly dependent on the dosage used. For example, in mice, naloxone at a low dose exacerbated the corticosterone response to stress, while at a higher dose the stressinduced corticosterone response was diminished (Kitchen and Rowlan 1984).

In turkey poults stressed with immobilisation, morphine $\left(5\right.$ and $\left.10 \mathrm{mg} \cdot \mathrm{kg}^{-1}\right)$ did not affect the hyperprolactinaemia induced by the stress (Ali et al. 1987), while a dose of $25 \mathrm{mg} \cdot \mathrm{kg}^{-1}$ was effective in lowering the level of prolactin. In unstressed turkey poults (Ali et al. 1987) and sheep (McMillen et al. 1979) morphine had no significant effect on prolactin concentration in plasma. 
Parrot and Thornton (1989) presented experimental evidence that endogenous and exogenous opioids modulate cortisol release in non-stressed sheep, and cortisol and prolactin secretion in sheep subjected to psychological stress (isolation from the flock). In non-stressed sheep, treatment with the opioid antagonist naloxone, but not with morphine or saline, increased cortisol by 36-48\%. In stressed sheep, however, cortisol concentrations were elevated throughout the 60-min sampling period after naloxone (by $161 \%$ ) or saline (by $150 \%$ ), but for only $20 \mathrm{~min}$ after morphine (by 112\%). Prolactin levels were also raised after saline and morphine, but were unchanged by naloxone. The response of sheep to morphine and naloxone was similar to that of primates, but was different from that of rats (Parrot and Thornton 1989).

In further experiments, Parrot and Goode (1993) found that, in unstressed sheep, i.v. injection of morphine decreased cortisol and increases prolactin plasma concentrations, and that naloxone induces the opposite effects. However, injection of morphine or naloxone intracerebroventricuarly did not cause a significant effect on cortisol or prolactin secretion. These results were consistent with the view that exogenous and endogenous opioids affect the pituitary to influence cortisol release in sheep but act also at the hypothalamic level to influence prolactin secretion.

As with benzodiazepines, the opioids, being expensive controlled addictive drugs that can be misused, represent a serious disadvantage that can preclude their routine use in cases of stress in domestic animals.

\section{CNS depressants (barbiturates)}

Administration of pentobarbitone $\left(20 \mathrm{mg} \cdot \mathrm{kg}^{-1}\right.$ i.v.) to goats subjected to transport stress was effective in blocking resting and stimulated plasma cortisol release and hyperglycaemia, and in antagonising the increase in respiratory and heart rates induced by the stress. Previously, variable results of the effect of pentobarbitone on surgery or drug-induced corticoid increases were reported in laboratory animals (see Sanhouri et al. 1991a, 1992 and references therein).

The mechanism of action of pentobarbitone as an anti-stressor agent has been suggested to be mediated directly on the pituitary to inhibit ACTH release, or more likely, at the hypothalamus to inhibit corticotrophin releasing factor (CRF) release. It is also possible that pentobarbitone has blocked the afferent arm of the cortisol response by reducing the sensory input traffic (Sanhouri et al. 1991).

The effects of pentobarbitone on respiratory and heart rates were due to inhibition of sympathoadrenal systems. As pentobarbitone is a non-selective CNS depressant acting, among others on GABA-ergic and dopaminergic neurones, the exact mechanism of its action is not well defined. Barbiturates suffer from the same disadvantages of opioids and benzodiazepines (see above). They are not useful in elucidating the mechanisms involved in the stress response because they lack selectivity, as they may act via GABA-ergic, dopaminergic, or other mechanisms.

6. Drugs with hormonal effects

6.1. Metyrapone

This is an adrenal cortex inhibitor that acts on specific steps of the synthesis of glucocorticoid hormones, the $\mathrm{P}_{45} 0_{1} \beta$. In young pigs metyrapone has been shown to effectively block cortisol (but not corticosterone) production in young pigs. Birrenkott and Ezzat (1983) tested the effect of caponization and adrenal cortical manipulation on subsequent heat stress survival. They have found that the corticosterone synthesis inhibitor metyrapone $\left(60 \mathrm{mg} \cdot \mathrm{kg}^{-1}\right)$ caused a significantly higher heat stress mortality in capons and 
sham-operated male chickens, than in capons receiving ACTH. This confirmed the important contribution of in the ability of young chickens to withstand environmental temperatures. In another experiment in chickens Freem an and Flack (1984) have shown that metyrapone $\left(75\right.$ and $\left.150 \mathrm{mg} \cdot \mathrm{kg}^{-1}\right)$ stimulated a hypercorticosteronaemia in fed but not starved birds that lasted for four hours. In the chicken, metyrapone, given $2 \mathrm{~h}$ earlier inhibited the response to exogenous ACTH. More recently, Calvo et al. (1998) tested the effect of metyrapone $\left(75 \mathrm{mg} \cdot \mathrm{kg}^{-1}\right)$ on some behavioural and neurochemical changes induced by restraint stress in rodents, and found that the drug was effective in preventing these changes. However, the experience with metyrapone in domestic animals is rather limited, and the drug has only been tested in chickens and pigs. Moreover, in chickens, it caused a differential effect on corticosterone level in blood depending on the state of feeding of the birds. Therefore, the usefulness of metyrapone as an anti-stressor is, at least, questionable.

\section{Dietary substances}

7.1. Magnesium $(\mathrm{Mg})$

Kietzmann and Jablonski (1985) found that, in pigs, the i.m. administration of $\mathrm{Mg}$ aspartate (3-4 mg. $\left.\mathrm{kg}^{-1}\right) 1 \mathrm{~h}$ before the application of a stressful stimulus, significantly reduced the parameters of stress measured (catecholamines and cortisol concentrations in blood). In stressed rats, the addition of the drug to the diet was also found to be useful in reducing the stress reactions (Kaemmerer and Kietzmann 1984).

In turkeys, the addition of $\mathrm{Mg}$ aspartate to the drinking water decreased pre-slaughter stress, as measured by the subsequent improvement in meat qualities, and reduced the severity of the "pale muscle condition" sometime seen during heat stress (Froning 1984).

In turkey poults subjected to immobilisation stress, $\mathrm{Mg}$ aspartate reduced the parameter of stress (hyperprolactinaemia) studied (Ali et al. 1987). The mode of action of $\mathrm{Mg}$ as an anti-stressor agent, and the status of $\mathrm{Mg}$ in blood of stressed animals are not certain. However, it has been suggested that $\mathrm{Mg}$ causes a generalised reduction in the activity of animals. It may also reduce the neural mechanisms that regulate prolactin release. In stressed rats, $\mathrm{Mg}$ depresses the level of circulating catecholamines (Kae mmerer and Kietzman 1984). Stressed pigs have lowered Mg plasma levels (Finko et al. 1982; Kietzmann and Jablonski 1985) and hypomagnesaemia has been associated with cold stress in ruminants (Achmadi et al. 2001) and heat stress in chickens (Donoghue et al. 1990). On the other hand, acute stress in rats has been shown to increase $\mathrm{Mg}$ concentration in the blood and decreases that in the cells of rats (Classen et al. 1971). Noise-induced stress in rats has been reported to cause a $15 \%$ deficit in plasma Mg concentration (Altura et al. 1992). This result is at variance with the recent report that indicated that noise stress in humans is associated with increased concentration of $\mathrm{Mg}$ in serum (Mocci et al. 2001). It appears that the status of $\mathrm{Mg}$ in stressed subjects depends on various factors that include species, type and duration of stress and other factors. More studies on the status of $\mathrm{Mg}$ (and other minerals and electrolytes) in stressed domestic animals seem warranted. In most of the experiments reported on $\mathrm{Mg}$, the salt used was $\mathrm{Mg}$ aspartate. It is not known whether the aspartate plays a role in the observed effect. More experiments with other salts may be warranted. However, $\mathrm{Mg}$ administration may conceivably induce some degree of imbalances in $\mathrm{Mg}$ and other related electrolytes (e.g. Ca).

\subsection{Tyrosine and other amino acids}

As far as we are aware, there is no information on the effect of tyrosine (a food constituent and catecholamines precursor) on stress in domestic animals. Recently, we have tested the effect of tyrosine (100 $\mathrm{mg} \cdot \mathrm{kg}^{-1}$, intravenously) on the response of Desert sheep to acute 
transportation stress. The amino acid treatment was found to significantly ameliorate the hormonal, biochemical and haematological effects of stress (Ali et al. 2001). In rats, this amino acid has been tested in rats subjected to acute uncontrollable stress (tail shock), and was found to antagonise the behavioural and neurochemical deficits induced by the stress (Reinstein et al. 1984). In humans, B anderet and Liberman (1989) have shown that tyrosine significantly decreased symptoms, adverse moods, and performance impairments in subjects subjected to $4.5 \mathrm{~h}$ of cold and hypoxia.

More work to evaluate tyrosine as an anti-stressor in domestic animals is warranted. Mormede and Dantzer (1979) tested the effect of loading pigs with tryptophan $\left(50-200 \mathrm{mg} \cdot \mathrm{kg}^{-1}\right)$ and found that it significantly reduced some responses of pigs to stress (fear and unavoidable shock). However, it failed to mitigate other types of stress responses (reaction to frustration, continuous avoidance response). It is known that increased tryptophan in the brain may be a general mechanism for several stressful stimuli, where it is converted to the neurotransmitter serotonin. In the blood tryptophan is present in bound and free forms. It is also established that the entry of tryptophan in the brain may be influenced by the plasma levels of free tryptophan (that is not bound to albumin) and, from competition for entry into the brain, by the plasma level of branched chain amino acids (BCAA). Hence it is expected that the oral administration of BCAA could prevent the increase in serotonin during stressful stimuli (reviewed by Castell et al. 1999). A decrease in plasma albumin concentration during stress (e.g. exercise or surgery) may be expected to increase plasma free tryptophan levels and therefore brain serotonin levels. Supplementation of diets of animals under stress with BCAA may be useful in counteracting the effects of an increase in plasma free tryptophan, and may therefore lessen the effects of stress in animals. However, it has been shown that intraperitoneal administration of tryptophan in early weaned piglets significantly decreases liquid diet intake (Baranyiová 1996). The mechanism of the suppressive effect of tryptophan on feed intake may be a complex one, involving several metabolites, hormones and autocoids, particularly serotonin (5-HT). The latter neurotransmitter has been shown to suppress feed intake in many species including chickens and piglets (Baranyiová 1990, 1991).

In rats, valine has been shown to prevent restraints stress-induced increases in brain tryptophan and serotonin turnover (Joseph et al. 1983). These actions were also accompanied by an attenuation of the corticosteroid response to restraint response. As far as we are aware valine has not been tried in domestic animals to ameliorate or prevent stress. More studies on the above amino acids and their combinations seem warranted.

\subsection{Ascorbic acid (vitamin C)}

Several authors have studied the effect of ascorbic acid on the biochemical and other signs of various types of stress in poultry and in rats. Stress is known to modulate ascorbic acid metabolism in the rat (Nakano and Suzuki 1984). It provokes a significant rise in the serum level of ascorbic acid, and a reduction in its concentration in skin, lung and adrenal glands. The addition of ascorbic acid [with or without acetyl salicylic acid (ASA)] to the diet of chickens has been reported to improve the productive performance of chickens under thermal stress (Oluyemi and Adebanjo 1978). Cross (1992) has shown that ascorbic acid $\left(100 \mathrm{mg} \cdot \mathrm{kg}^{-1}\right.$ feed) ameliorated various types of stress in chickens (rough handling, fasting, unusual sound and bacterial and viral infections). The effect of ascorbic acid on the stress fear of chickens being prepared for slaughter (cooping/starvation) has been studied by Satterlee et al. (1989). They have found that the addition of drinking water with ascorbic acid (1200 parts per million) significantly reduced the stress response (the rise in plasma corticosterone and heterophil/lymphocyte ratio). The beneficial effect of ascorbic acid in stressful situations in chickens has also been reported by McKee and Harrison (1995), 
McKee and his colleagues (1997) and more recently by Zulkifili et al. (2000). The mechanism(s) of action of ascorbic acid as an anti-stressor agent is not fully understood. However, ascorbic acid is thought to boost humoral and cellular immunity, increase resistance to infection, increase the defensive mechanisms and the anti-oxidant status of the animal, reduce the detrimental effects of certain eicosanoids. On the other hand, others, however, have shown that ascorbic acid and ASA in the diet at various concentrations are without beneficial effect on broiler growth or feed efficiency (Stilborn et al. 1988). The discrepancy may be ascribed to the severity of the stress applied, the experimental conditions, or to other factors. Although the anti-stressor effect of ascorbic acid has not always consistently been reported, the vitamin (being water soluble, safe and rather inexpensive) seems a very suitable agent for mass medication in poultry and ruminants.

\subsection{Other dietary substances}

Enrichment of the diets of calves with glucose in early postnatal period decreased serum cortisol concentration, while supplementation of the diets with casein $(25 \%$ more than in controls) caused the opposite effect (Friedrich 1995). These effects lasted for a few days after the termination of the diet supplementation. The mechanism of these actions is not clear but they corroborate data from human studies that seem to suggest that consumption of carbohydrate-rich meals increase blood glucose levels and the plasma ration of tryptophan to other large neutral amino acids more than when a protein-rich meals are consumed (Christensen and Radig 1993), and that those on carbohydrate-rich diets may have an increased ability to cope with stress (Markus et al. 2000).

The effect of inclusion of either casein or soya as the protein source was studied in cats subjected to 2-h immobilisation stress (Thibault and Roberge 1988). It was found that the cats consuming the casein had greater resistance to stress than those consuming soya. These results seem to emphasise not only the importance of the percentage of protein consumed in the susceptibility or resistance of the animal to stress, but also the quality of protein consumed. Although the inclusion of the dietary substances mentioned above (glucose, soy, casein) in animal feed may modify their response to stress, more experiments in large numbers of animals of a variety of species are required before firm conclusions on the efficacy and safety of these agents are reached. The economics of their inclusion is also an important factor in their consideration as anti-stress agents.

\section{Conclusions}

It would appear from aforementioned account that most of the drugs tested or used, as anti-stressor agents are CNS depressant. These are expensive, difficult to apply to large numbers of animals, and some of them (e.g. opioids, barbiturates and benzodiazepines) are controlled drugs (i.e. only licensed pharmacists and veterinarians are permitted to sell). Therefore their practical utilisation is severely limited. However, it should be noted that, as the CNS is an essential and early component of the "stress response", and would also be involved in the perception of a stimulus as aversive, an agent that affects only the peripheral component(s) in the stress response and doses not act on the CNS, would not be expected to be beneficial to the stressed animal, unless it removes or, at least, mitigate a harmful consequence of the stress response. From a welfare point of view, the use of vitamins (notably ascorbic acid), amino acids and other dietary substances may provide a more practical and less expensive alternative to the CNS drugs, if they can be shown to removes or, at least, mitigate a harmful consequence of the stress response. These biological substances may also have fewer side effects than chemical drugs. However, more studies are needed to evaluate the safety, efficacy and economics of these dietary substances in different 
species subjected to different types of stressful stimuli. Investigations of "natural" substances such as melatonin as an anti-stress agent in domestic animals are warranted. Melatonin has recently been shown to exhibit significant anti-stress effects in laboratory animals (e.g. Brotto et al. 2001).

\section{Hodnocení léčiv používaných ke zmírnění vlivu stresových faktorů na domácí zvířata}

Doposud neexistuje všeobecná názorová shoda v tom, co vytváríi stresový podnět pro zvírata, ani na metody kvantifikující odpověd zvířat či cesty, kterými lze stres zmírnit nebo mu zabránit.

$\mathrm{V}$ předložené práci byl vyhodnocován účinek vybraných léčiv a jiných preparátů na klinické, biochemické, hormonální a jiné změny vyvolané působením různých stresorů na domácí zvířata. Testované preparáty patřily k následujícím skupinám: sedativa, která jsou adrenergními agonisty a antagonisty (např. xylazin, prazosin a acepromazin), dopamin, benzodiazepiny (např. diazepam), opioidní agonisté (např. morfin), depresiva centrálního nervového aparátu (např. barbituráty), léky s hormonálním účinkem (např. metyrapon) a dietetické látky (magnesium aspartát, tyrosin a kyselina askorbová).

Většina těchto preparátů byla při zmírňování některých aspektů změn navozených stresovými faktory $\mathrm{v}$ různém stupni účinná. Zdá se, že bez ohledu na různorodé a často protikladné mechanismy působení, mají tyto preparáty antagonistický vliv na jeden či více různých aspektů odpovědi na stres. Je to odraz komplexnosti odpovědi na stres.

Používání těchto látek ke zmírnění či zabránění stresu u zviřrat má také mimořádný etický význam. Poznatků o jejich působení může být využito i ke zlepšení našeho chápání komplexu fyziologických a behaviorálních aspektů stresu. Aplikace vitamínů, aminokyselin a jiných dietetických doplňků by mohla z hlediska pohody zvířat znamenat levnější, a tedy dostupnější, alternativní př́istup při volbě antistresových preparátů, pokud se prokáže, že jsou schopné plně odstranit nebo alespoň zmírnit škodlivé následky odpovědí na stres. Při jejich aplikaci nelze vyloučit ani slabé vedlejší účinky.

\section{References}

ACHMADI, J, SANO, H, TERASHIMA, Y 2001: Effect of hypomagnesemia and cold exposure on tissue responsiveness to insulin in sheep given a low magnesium and high potassium diet. Domest Animal Endocrinol 20: $101-108$

AGNES, F, SARTORELLI, P, ABDI, BH, LOCATELLI, A 1990: Effect of transport loading or noise on blood biochemical variables in calves. Amer J Vet Res 51: 1679-1681

ALAM, MGS, DOBSON, H, FITZPATRICK, RJ 1986: Endocrine responses to different doses of ACTH in cows. Brit Vet J 142: 239-245

ALI, BH, AL-QARAWI, AA, MOUSA, HM, MOHAMED, SM 2001: The effect of tyrosine on stress associated with transport in Desert sheep. Vet Res Com 25: 503-510

ALI, BH, SILISBY, JL, El HALAWANI, ME 1987: The effect of magnesium aspartate, xylazine and morphine on the immobilization-induced increase in the levels of prolactin in turkey plasma. J Vet Pharmacol Therap 10: 119-126

ALTURA, BM, ALTURA, BT, GEBREWOLD, A, ISING, H, GUNTHER, T 1992: Noise-induced hypertension and magnesium in rats: relationship to microcirculation and calcium. J Appl Physiol 72: 194-202

BANDERET, LE, LIEBERMAN, HR 1989: Treatment with tyrosine, a neurotransmitter precursor, reduces environmental stress in humans. Brain Res Bull 22: 759-762

BARANYIOVÁ, E 1990: Effects of serotonin on the food intake in chickens in the post-hatching period. Acta vet Brno 59: 23-33

BARANYIOVÁ, E 1991: Effect of serotonin on food intake by piglets during the early postnatal period. Acta vet Brno 60: $127-136$

BARANYIOVÁ, E 1996: Intraperitoneal administration of tryptophan decreased liquid diet intake in early weaned piglets. Acta vet Brno 65: 185-192

BENSON, GJ, GRUBB, TL, NEFF-DAVIS, C, OLSON, WA, THURMON, JC LINDER, DL, TRANQUILLI, WJ, VANIO, O 2000: Perioperative stress response in the dog: effect of pre-emptive administration of medetomidine. Vet Surg 29: 85-91

BIRRENKOTT, GP, EZZAT, AR 1983: Response of broilers and capons to heat stress following adrenal manipulation. Poult Sci 62: 702-704 
BLOKHUIS, HJ, EKKEL, ED, KORTE, SM, HOPSTER, H, van REENEN, CG 2000: Farm animal welfare research in interaction with society. Vet Quart 22: 217- 222

BOBEK, S, NIEZGODA, J, PIERZCHALA, K, LITYNSKI, P, SECHMAN, A1986: Changes in circulating iodothyronines, cortisol and endogenous thiocyanate in sheep during emotional stress caused by isolation of the animals from the flock. J Vet Med (A) 33: 698-705

BREARLEY, JC, DOBSON, H, JONES, RS 1990: Investigations into the effect of two sedatives on the stress response in cattle. J Vet Pharmacol Ther 13: $367-377$

BROTTO, LA, GORZALKA, BB, LA MARNE, AK 2001: Melatonin protects against the effects of chronic stress on sexual behavior in male rats. Neuroreport 12: 3465-3469

CALVO, N, MARTIJENA, ID, MOLINA, VA, VOLOSIN, M 1998: Metyrapone pretreatment prevents the behavioural and neurochemical sequel induced by stress. Brain Res 800: 227-235

CASTELL, LM, YAMAMOTO, T, PHOENIX, J, NEWSHOLME, EA 1999: The role of tryptophan in fatigue in different conditions of stress. Adv Exp Med Biol 467: 697-704

CHRISTENSEN, L, REDIG, C 1993: Effect of meal composition on mood. Behav Neurosci 107: 346-353

CLASSEN, HG, MARQUARDT, P, SPATH, M, SCHUMACHER, KA 1971: Hypermagnesemia following exposure to acute stress. Pharmacol 5: 287-294

COOK, C, JACOBSON, LH 1996: Heart rate as a measure of adaptation to stress in cattle. Austral Vet J 74: 28-29

COOPER, GM, PATERSON, JL, MASHITER, K, HALL, GM 1980: Beta-adrenergic blockade and the metabolic response to surgery. Brit J Anesth 52: 1231-1236

DOBSON, H, TEBBLE, JE, SMITH, RF, WARD, WR 2001: Is stress really important? Theriogenology $\mathbf{5 5}$ $65-73$

DONOGHUE, DJ, KRUEGER, WF, DONOGHUE, AM, BYRD, JA, ALI, BH, EL-HALAWANI, ME 1990: Magnesium-Aspartate-Hydrochloride reduces weight-loss in heat-stressed laying hens. Poult Sci 69: 1862-1868

EIGLER, N, SACCA, L, SHERWIN, RS 1979: Synergistic interactions of physiologic increments of glucagon, epinephrine, and cortisol in the dog. J Clin Invest. 63: 114-123

EL-HALAWANI, ME, SILSBY, JL, FEHRER, SC, BEHNKE, EJ 1985: The influence of acute or repeated immobilization on plasma prolactin levels in the turkey. Gen Comp Endocrinol 59: 410-415

FAHRINGER, EF, FOLEY, EL, REDGATE, ES 1974: Pituitary adrenal responses to ketamine and the inhibition of the response by catecholaminergic blockade. Neuroendocrinology 14: 151-164

FEENSTRA, MG 2000: Dopamine and noradrenaline release in the prefrontal cortex in relation to unconditioned and conditioned stress and reward. Prog Brain Res 126: 133-163

FITKO R., KOWALSKI, A, BRZEZINSKA, M, HYNIEWIECKA, A 1982: Effect of diazepam, propranolol and guanethidine on physiological indices of immobilized swine. Medyc Weterynar 8: 538-541

FREEMAN, BM., FLACK, IH 1984: Effects of metyrapone on plasma corticosterone concentration in Gallus domesticus. Comp Biochem Physiol C, 79: 113-116

FRIEDRICH, M 1995: Effects of diet enrichment with glucose and casein on blood cortisol concentration of calves in early postnatal period. Arch Vet Pol 35: 117-125

FRONING, GW 1984: Effect of Cytran in drinking water on preslaughter stress and turkey meat quality characteristics. Poult Sci $\mathbf{6 3}$ (Suppl), 103

GROSS, WB 1992: Effects of ascorbic acid on stress and disease in chickens. Avian Dis 36: 688-692

HARGREAVES, AL, HUSTON, GD 1990: Some effects of repeated handling on stress response in sheep. Appl Anim Behav Sci 26: 253-265

JACOSON, LH, COOK, CJ 1998: Partitioning psychological and physical sources of transport-related stress in young cattle. Vet J 155: 205-208

JEPHCOTT, EH, McMILLEN, IC, CONGDON, A, THORBURN, GD 1988: Electroimmobilisation and ovine plasma cortisol concentration: effect of current intensity, current duration and diazepam. Res Vet Sci 44: 21

JOSEPH, MH, KENNETT, GA 1983: Corticosteroid response to stress depend upon increased tryptophan availability. Psychopharmacol (Berlin), 79: 79-81

KAEMMERER, K, KEITZMANN, M 1984: Studies on magnesium. III. Influence of magnesium aspartatehydrochloride on the stress reactions in animals with magnesium deficiency. Zentbl VetMed A, 31: 321-333

KIETZMANN, K, JABLONSKI, H 1985: Zur Stressabschirmung mit magnesiumaspartat hydrochlorid beim Schwein. Prakt Tierarzt 66: 331-335

KITCHEN, I, ROWAN, KM 1984: Differences in the effects of mu-opioid and delta-opioid receptor antagonists upon plasma-corticosterone levels in stressed mice. Eur J Pharmacol 101: 153-156

KNOWLES, TG 1998: A review of the road transport of slaughter sheep. Vet Rec 143: 212-219

LISTER, D, HALL, GM, LUCKE, JN 1976: Procine malignant hyperthermia. III. Adrenergic blockade. Brit J Anaesth 48: 831-837

MARKUS, R, PANHUYSEN, G, TUITEN, A, KOPPESCHAAR, H 2000: Effects of food on cortisol and mood in vulnerable subjects under controllable and uncontrollable stress. Physiol Behav 70: 333-342

McKEE, JS, HARRISON, PC 1995: Effects of supplemental ascorbic acid on the performance of broiler chickens exposed to multiple concurrent stressors. Poult Sci 74: 1772-1785

McKEE, JS, HARRISON, PC, RISKOWSKI, GL 1997: Effect of supplemental ascorbic acid on the energy conversion of broiler chicks during heat stress and feed withdrawal. Poult Sci 76: 1278-1286 
McMILLEN, IC, COOKSON, I, YHORBURN, GD, ROBINSON, JS 1979: Lack of effect of morphine and naloxone on plasma concentrations of prolactin and GH in fetal and adult sheep. Acta Endocrinol 91: 78

MOCCI, F, CANALIS, P, TOMASI, PA, CASU, F, PETTINATO, S 2001: The effect of noise on serum and urinary magnesium and catecholamines in humans. Occup Med (London), 51: 56-61

MORMEDE, P, DANTZER, R 1979: Effect of a tryptophan lead on the swine adrenal cortex reactivity and behavioral response to stress. CR Seances Soc Phil 173: 569-575

NAKANO, K, SUZUKI, S 1984: Stress-induced change in the levels of ascorbic acid and histamine in rats. J Nutr 114: $1602-1608$

NIKPOUR, K, SALIMI, MM 1979: Xylazine as an anti-stressor agent in poultry production. Indian J Animal Sci 49: $828-830$

OLUYEMI, JA, ADEBANJO, A 1978: Supplementation of diets with vitamin C and aspirin to improve the performance of poultry under thermal stress. Bull Animal Health Prod Africa 26: 252-257

PARROTT, RF, GOODE, JA 1993: Central effects of naloxone and selected opioid agonists on cortisol and prolactin secretion in non-stressed sheep. Gen Pharmacol 24: 101-103

PARROTT, RF, THORNTON, SN 1989: Opioid influences on pituitary function in sheep under basal conditions and during psychological stress. Psychoneuroendocrinology 14: 451-459

PHAGOT, JB, SMITH, RF, DOBSON, H 1997: The influence of stress on neuroendocrine control of the hypothalamic-pituitary-ovarian axis. Vet Bull 67: 545-567

RAGO, L, MACDONALD, E, SAANO, V, AIRAKSINEN, MM 1991: The effect of medetomidine on GABA and benzodiazepine receptors in vivo: lack of anxiolytic but some evidence of possible stress-protective activity. Pharmacol Toxicol 69: 81-86

REINHEIM, B, HORSBERG, TE, SOLI, NE, RYENG, KA, ARNEMO, JM 2000: The effect of medetomidine and its reversal with atipamezole on plasma cortisol and noradrenaline in cattle and sheep. J Vet Pharmacol Therap 23: 379-387

REINSTEIN, DK, LEHNERT, H, SCOTT, NA, WURTMAN, RJ 1984: Tyrosine prevents behavioral and neurochemical correlates of acute stress in rats. Life Sci 34: 2225-2231

SANHOURI, AA, JONES, RS, DOBSON, H.1991c: Preliminary results on the effects of diazepam on physiological responses to transport in male goats. Brit Vet J 147: 388-389

SANHOURI, AA, JONES, RS, DOBSON, H 1990: Plasma concentrations of cortisol, testosterone, glucose and blood gases in male goats during anaesthesia with pentobarbitone sodium. Brit Vet J 146: 36-42

SANHOURI, AA, JONES, RS, DOBSON, H 1991a: Pentobarbitone inhibits the stress response to transport in male goats. Brit Vet J 147: 42-48

SANHOURI, AA, JONES, RS, DOBSON, H 1991b. Prazosin and propranolol and the stress response to transport in male goats; a preliminary study. J Vet Pharmacol Therap 14: 421-425

SANHOURI, AA, JONES, RS, DOBSON, H 1992: Effect of xylazine on the stress response to transport in male goats. Brit Vet J 148: 119-128

SANHOURI, AA, JONES, RS, DOBSON, H 1993: Azaperone, pimozide and bromocryptine and the stress response to transport in male goats: a preliminary study. J Vet Pharmacol Therap 15: 107-111

SATTERLEE, DJ, AGUILERA-QUINTANA, I, MUNN, BJ, KRAUTMANN, BA 1989: Vitamin C amelioration of the adrenal stress response in broiler chickens being prepared for slaughter. Comp Biochem Physiol A 94: $569-574$

STILBORN, HL, HARRIS, GC, BOTTJE, WG, WALDROUP, PW 1988: Ascorbic acid and acetylsalicylic acid (aspirin) in the diet of broilers maintained under heat stress conditions. Poult Sci 67: 1183-1187

SWIDERSKA-KOLACZ, G, KOLACZ, A, KLUSEK, J 1997: The influence of starvation, transport and crowding on the level of thiol groups in pigs. J Animal Physiol Animal Nutr 78: 161-166

TANAKA, M, KOHON, Y, NAKAGAWA, R, IDA, Y, LIMORI, K, HOOKI, Y, TSUDA, A, NAGASAKI, A 1982: Naloxone enhances stress-induced increases in noradrenaline turnover in specific regions in rats. Life Sci 30: $1663-1669$

TANAKA, M, KOHON, Y, TSUDA, W, NAKAGAWA, R, IDA, Y, LIMORI, K, HOOKI, Y 1983: Differential effects of morphine on noradrenaline release in brain regions of stressed and non-stressed rats. Brain Res 275 : $105-115$

THIBAULT, L, ROBERGE, AG 1988: Dietary protein and carbohydrate effects on blood parameters related to stress in cat. Physiol Behav 42: 1-5

TSUJI, H, ASOH, T, SHIRASKA, C, TAKEUCHI, Y 1980: Inhibition of metabolic responses to surgery with adrenergic blockade. Brit J Surg 67: 503-505

WARRIS, PD 1995: The welfare of animals during transport. Vet Ann 36: 73-81

ZULKIFILI, I., CHE NORMA, MT, CHONG, CH, LOH, TC 2000: Heterophil to lymphocyte ratio and tonic immobility reactions to preslaughter handling in broiler chickens treated with ascorbic acid. Poult Sci 79: 402406 